Article

\title{
Growth, Physiological, Biochemical, and Transcriptional Responses to Drought Stress in Seedlings of Medicago sativa L., Medicago arborea $\mathrm{L}$. and Their Hybrid (Alborea)
}

\author{
Eleni Tani ${ }^{1}$, Evangelia G. Chronopoulou ${ }^{2}$, Nikolaos E. Labrou ${ }^{2} \oplus$, Effie Sarri ${ }^{1}$, Maria Goufa ${ }^{1}$, \\ Xristina Vaharidi ${ }^{1}$, Alexia Tornesaki ${ }^{1}$, Maria Psychogiou ${ }^{3}$, Penelope J. Bebeli ${ }^{1}$ and \\ Eleni M. Abraham ${ }^{4, *(D)}$ \\ 1 Department of Crop Science, Laboratory of Plant Breeding and Biometry, Agricultural University of Athens, \\ Iera Odos 75, 11855 Athens, Greece; etani@aua.gr (E.T.); efisarri.18@gmail.com (E.S.); marog@aua.gr (M.G.); \\ vxristina@yahoo.com (X.V.); aleksia.tornesaki@gmail.com (A.T.); bebeli@aua.gr (P.J.B.) \\ 2 Laboratory of Enzyme Technology, Department of Biotechnology, School of Food, Biotechnology and \\ Development, Agricultural University of Athens, Iera Odos 75, 11855-Athens, Greece; \\ exronop@gmail.com (E.G.C.); Lambrou@aua.gr (N.E.L.) \\ 3 Department of Natural Resources Management and Agricultural Engineering, Laboratory of Agricultural \\ Hydraulics, Agricultural University of Athens, Iera Odos 75, 11855 Athens, Greece; mariapsy1@gmail.com \\ 4 Faculty of Agriculture, Forestry and Natural Environment, School of Forestry and Natural Environment, \\ Aristotle University of Thessaloniki, 54124 Thessaloniki, Greece \\ * Correspondence: eabraham@for.auth.gr; Tel.: +30-2310992301
}

Received: 1 December 2018; Accepted: 15 January 2019; Published: 19 January 2019

\begin{abstract}
Medicago sativa L. is a tetraploid perennial forage legume of great agronomical interest. The increasing need for its use under water-deficit conditions as well as low-input systems demands further improvement of its drought tolerance. On the other hand, Medicagoarborea L. is a perennial leguminous shrub, which is knownas a drought-tolerant species. In the present study, drought stress responses of the aforementioned medicago species, along with their hybrid, named Alborea, were comparatively assayed at the morphological, physiological, biochemical, and transcriptional levels. In particular, transcript abundance of representative genes that: (a) control ion transport, intracellular $\mathrm{Na}^{+} / \mathrm{H}^{+}$antiporters(NHX1) and rare cold inducible $2 \mathrm{~A}(\mathrm{RCI} 2 \mathrm{~A})$; (b) have an osmotic function $\Delta 1$-pyrroline-5-carboxylate synthetase 1 (P5CS1); and (c) participate in signaling pathways and control cell growth and leaf function stress-induced mitogen-activated protein kinases kinases (SIMKK), Zinc Finger $(Z F N)$, apetala2/ethylene-responsive element binding (AP2/EREB), basic leucine zipper (bzip) and Medicago sativa Helicase 1(MH1) were evaluated. Under well-watered conditions, the studied population of Alborea showed the highest stem elongation rate and photosynthetic rate that were dramatically reduced under drought conditions compared to M. sativa and M. arborea. Under drought conditions, the studied population of $M$. arborea showed less reduction of relative water content, all gas-exchange parameters, less lipid peroxidation, and more antioxidant capacity. Moreover, transcriptional analysis demonstrated that the population of $M$. arborea exhibited significantly higher transcript levels of drought-responsive genes in both leaves and roots under drought stress conditions. M. sativa has better antioxidant capacity than Alborea and had a higher induction of stress-related genes, thus it performs better than Alborea under drought conditions. Among the studied genes, it seems that $A P 2 / E R E B$ play a critical role in the response of the studied population to drought stress.
\end{abstract}

Keywords: Medicago species; water deficit; gene expression; antioxidant capacity; leaf gas-exchange parameters 


\section{Introduction}

Drought is one of the most important environmental stresses limiting crop yields and productivity all over the world [1]. As the world's population is increasing rapidly, the amount of available agricultural land is shrinking mainly due to habitat use and climate change. Therefore, it is of great importance to exploit drought-affected land to meet the increasing world food demand and energy needs [2].

Plants react to the water deficit by the regulation of different physiological and biochemical processes such as water relation, gas exchange, photosynthesis, and the metabolism of organic compounds [3] as well as by adjustments of the membrane system [4]. Water deficit severely affects the photosynthesis process in all its phases mainly due to decrease of $\mathrm{CO}_{2}$ diffusion to the chloroplast and to metabolic constraints [5]. In addition, plants accumulate compatible solutes such as proline that can stabilize proteins, to facilitate water absorption by decreasing the cytoplasmic osmotic potential, and to remove excess levels of Reactive Oxygen Species (ROS) maintaining cellular redox balance $[1,6]$. Plants possess an efficient antioxidant (enzymatic and non-enzymatic) defense system to cope with ROS-induced oxidative stress [7-9]. Antioxidant enzymes such as superoxide dismutase (SOD), and peroxidase (POD) could suppress the oxidative damage. The contribution of antioxidants to drought tolerance has been reported in several cases [10-12]. Plants respond to drought stress at the molecular level mainly by altered gene expression. Several different pathways are activated that interact with each other, forming a complex network which finally leads to modification of target proteins responsible for cellular responses at the physiological, biochemical, and molecular levels $[13,14]$.

Alfalfa or Medicago sativa L. (M. sativa) is a tetraploid perennial forage legume of great agronomical interest, due to its low production cost and high nutritive value. Moreover, its deep noduled-root system improves soil properties and it is a source of biologically fixed nitrogen that also prevents water loss in semi-dry lands [15]. Recently, there is an increasing interest for its use as a bioenergy feedstock [16]. Furthermore, the tendency to shift from high-input farming systems based on inorganic-N fertilizers to low-input systems, increases the need for alfalfa. Previous agronomical, physiological, and biochemical studies suggest that alfalfa is a plant species relatively tolerant to drought. However, its use under water-deficit conditions as well as low-input systems, demands further improvement of its drought tolerance [17]. Compared to other crop species, restricted information is available regarding mechanisms by which genetic and physiological factors contribute to drought tolerance in alfalfa. This is mainly due to its large, tetraploid genome and out-crossing nature both of which hinder the genomic and genetic research. Nevertheless, the use of -omic technologies shed some light on the mechanisms underlying alfalfa drought tolerance [18-20]. However, comparative studies on the expression of drought-induced genes in different medicago species are limited.

Medicago arborea L. (M. arborea) is a perennial leguminous shrub that is well adapted to the Mediterranean area and is used for forage production during summer and winter. It is also considered to be the oldest species of the genus and is known as a drought-tolerant species [21]. Researchers have attempted the introgression of favorable traits from $M$. arborea genome to $M$. sativa such as drought tolerance. Hybrids between M. sativa and M. arborea named Alborea have been produced in the USA and Australia [22,23].

In our previous work [24], transcriptional responses of several salt induced genes have been studied in the parent species and their hybrid. The aforementioned genes had been categorized into three groups: a. genes encoding ion transporters, intracellular $\mathrm{Na}^{+} / \mathrm{H}^{+}$antiporters (NHX1) and rare cold inducible $2 A$ (RCI2A), b. osmolytes, $\triangle 1$-pyrroline-5-carboxylate synthetase 1 (P5CS1) and c. transcription factors and signal transduction proteins, apetala2/ethylene-responsive element binding (AP2/EREB), stress-induced mitogen-activated protein kinases kinases(SIMKK), Zinc Finger (ZFN)). The initial responses of plants to salt and drought stress are similar as they must cope with water deficit in both stresses [25]. In this regard, the aim of the present work was to study the transcriptional responses of the same 
set of genes in the parental species and Alborea under drought stress. Additionally, in the present study, we have investigated the expression of two more gene, a DEAD-box helicase gene previously name Medicago sativa Helicase 1 (MH1), possibly involved in ROS scavenging [26] and a basic leucine zipper (bzip) transcription factor previously reported to play a role in both drought and salt tolerance in M. sativa [27]. Our main interest was to explore the mechanisms for drought tolerance of the parental species and their hybrid giving special attention to leaf gas-exchange parameters, antioxidant capacity and membrane stability in drought conditions.

\section{Materials and Methods}

\subsection{Plant Material}

The seeds of M. arborea, M. sativa and Alborea used in the present study was obtained from E. Bingham from the Agronomy Department, University of -Madison- Wisconsin,,Wisconsin, United States. The development of Alborea was described in detail by [22,24].

\subsection{Seeds Pretreatment}

Seeds of parental species along with their hybrid (hereafter entries) were scarified as it was described by [24] Then the seeds were placed on agar plates, turned upside down and remained at $4{ }^{\circ} \mathrm{C}$ overnight. Finally, they were incubated to $20^{\circ} \mathrm{C}$ for $3-4$ days in the dark to ensure uniform germination.

\subsection{Growth Conditions and Drought Treatment}

Thirty germinated seedlings of the entries were transferred into $10 \mathrm{~cm}$ pots containing a commercial growing medium (Kronos N 50-300 mg/L, $\mathrm{P}_{2} \mathrm{O}_{5} 80-300 \mathrm{mg} / \mathrm{L}, \mathrm{K}_{2} \mathrm{O}$ 80-300 mg/L, $\mathrm{pH} 5-6.5$, salinity $<1.75 \mathrm{~g} / \mathrm{L}$ ) and were placed in a growth chamber under a $16 / 8 \mathrm{~h}$ day/night regime, $23{ }^{\circ} \mathrm{C}, 55-65 \%$ relative humidity in a completely randomized block design. All the pots were normally watered in the growth chamber for four weeks before the implementation of the drought stress. Twenty-four plants per each entry were selected according to their uniformity of growth. Half of the plants were put under drought stress imposition by withholding water (drought treatment) for almost three weeks while another half were maintained in optimal water availability conditions (control) until harvesting or used for physiological measurement. Each treatment had 4 replicates consisting of three plants. The controls were irrigated with Hoagland solution [28] twice during the experiment. All pots were randomized within each treatment biweekly. The drought treatment was initiated on the 20th of November and was completed on the 7th of December. Shoots and roots were individually harvestedand immediately placed into liquid nitrogen. All plants during harvest were in the vegetative stage, and their roots did not show nodules.

\subsection{Growth and Physiological Parameters}

The stem length was measured every three days during the experimental period. Stem elongation rate (SER) was calculated as follow: $(\mathrm{SER})=(\mathrm{T} 2-\mathrm{T} 1) / \mathrm{t}$, where $\mathrm{T} 1$ and $\mathrm{T} 2$ are the stem length at the beginning and at the end of a time $(\mathrm{T})$ respectively.

Leaf relative water content (RWC) was determined weekly according to the following equation RWC $=(\mathrm{FW}-\mathrm{DW}) /(\mathrm{SW}-\mathrm{DW}) * 100$ [29] where FW is leaf Fresh Weight, DW is leaf Dry Weight after being dried at $85^{\circ} \mathrm{C}$ for $48 \mathrm{~h}$ and SW is turgid weight of leaves after soaking in water for $24 \mathrm{~h}$ at room temperature $\left(20^{\circ} \mathrm{C}\right)$.

Leaf gas-exchange parameters (net photosynthetic rate (Pn), stomatal conductance (gs), and transpiration rate (E)), were measured twice, after the 1st and 2nd week of drought stress, using the upper fully developed leaves. The measurements were carried out with a portable phytosynthesis system Li-6400 (LiCor, Lincoln, NE, USA) under constant conditions, air flow rate $500 \mu \mathrm{mol} \mathrm{s}{ }^{-1}$, PAR500 $\mu \mathrm{mol} \mathrm{m}{ }^{-2} \mathrm{~s}^{-1}, 400 \mu \mathrm{mol} \mathrm{CO} \mathrm{mol}^{-1}$, while leaf temperature ranged between $19^{\circ} \mathrm{C}$ and $23^{\circ} \mathrm{C}$. Water use efficiency (WUE) was calculated as the ratio between Pn and E. 


\subsection{Sample Preparation for Antioxidant Assays}

For enzyme antioxidant assays, plant extracts were prepared, from frozen $\left(-80^{\circ} \mathrm{C}\right)$ leaf and root tissues. The tissues were powdered with liquid nitrogen and were extracted (solid tissue/buffer ratio was 1:10) with ice-cold $50 \mathrm{mM}$ Potassium phosphate buffer ( $\mathrm{pH}$ 6) containing $0.1 \mathrm{mM}$ EDTA and $1 \%$ $(w / v)$ polyvinylpyrrolidone (PVP). Samples were centrifuged at 13,000 rpm for $5 \mathrm{~min}$. The supernatants were collected and used for antioxidant and enzyme activity assays. All assays were performed in duplicate.

\subsection{Total Antioxidant Capacity Assays}

Ferric Reducing Antioxidant Power (FRAP) assays were performed according to [30]. The FRAP reagent was freshly prepared by adding $10 \mathrm{mM}$ of 2,4,6-Tris (2-pyridyl)-1,3,5-triazine (TPTZ) (dissolved in $40 \mathrm{mM}$ of $\mathrm{HCl}$ ), $20 \mathrm{mM}$ of $\mathrm{FeCl}_{3}$ and $300 \mathrm{mM}$ of acetate buffer (pH 3.6) at a ratio of 1:1:10. Total antioxidant capacity (TAC) based on FRAP, was expressed as $\mu \mathrm{g}$ ascorbic acid equivalents/mg of FW. 2,2'-Azino-bis 3-ethylbenzothiazoline-6-sulphonic acid (ABTS) assays were accomplished according to published methods $[31,32]$. The results were expressed as \% radical scavenging activities/mg of FW.

\section{7. $M D A$}

Malondialdehyde (MDA) was measured by the colorimetric method described by [33]. Trichloroacetic acid $0.1 \%(w / v)$ was added in the extracts at a ration 4:1. After centrifugation $(10 \mathrm{~min}$, $\left.13,000 \mathrm{rpm}, 4^{\circ} \mathrm{C}\right)$, the supernatant was collected $(500 \mu \mathrm{L})$ and mixed with $1 \mathrm{~mL}$ volume of $20 \%(w / v)$ trichloroacetic acid solution and $0.5 \%$ thiobarbituric acid (TBA) and the sample incubated at $95{ }^{\circ} \mathrm{C}$ for $25 \mathrm{~min}$. The reaction was stopped by incubating on ice. The samples then centrifuged at 13,000 rpm for $5 \mathrm{~min}$. The absorption of supernatant was recorded at $532 \mathrm{~nm}$ as described by [34]. The amount of MDA was calculated using as extinction coefficient $155 \mathrm{mM}^{-1} \mathrm{~cm}^{-1}$. The results were expressed as nmol MDA/mg of fresh tissue.

\subsection{Antioxidant Enzyme Assays}

SOD activity was determined according to [35] by measuring the inhibition of cytochrome $\mathrm{c}$ reduction in a coupled enzyme system with xanthine oxidase at $\mathrm{pH} 7.8$ and $25^{\circ} \mathrm{C}$. In a $1 \mathrm{~mL}$ reaction mix, containing $50 \mathrm{mM}$ potassium phosphate, $0.1 \mathrm{mM}$ EDTA, $0.01 \mathrm{mMcytochrome} \mathrm{c}, 0.05 \mathrm{mM}$ xanthine, 0.005-unit xanthine oxidase and the appropriate volume of plant extract. SOD activity was determined at the absorption of $500 \mathrm{~nm}$. One unit of enzyme activity was taken as the quantity of enzyme, which reduced the absorbance reading of uninhibited rate to $50 \%$.

POD activity was determined at $436 \mathrm{~nm}$ according to the method of [36]. The method is based on the conversion of guaiacol to tetraguaiacol $\left(\varepsilon=26.6 \mathrm{mM}^{-1} \mathrm{~cm}^{-1}\right)$. The reaction mixture contained $100 \mathrm{mM}$ Potassium phosphate buffer ( $\mathrm{pH} 7.0$ ), guaiacol $20 \mathrm{mM}, \mathrm{H}_{2} \mathrm{O}_{2} 10 \mathrm{mM}$ and plant extract. The increase in absorbance was recorded at $436 \mathrm{~nm}$ for $3 \mathrm{~min}$. The results were expressed as $\mathrm{U} / \mathrm{mg}$ of protein. One unit of enzyme activity is defined as the amount of enzyme that catalyses the turnover of $1 \mu \mathrm{mol}$ of substrate per min.

\subsection{Protein Determination}

The protein content of samples was determined according to the Bradford method, using bovine serum albumin as a standard [37]. Results were expressed as $\mathrm{mg}$ of protein/mg fresh tissue.

\subsection{Primer Design}

Primer sequences were designed based on expressed sequences tags (EST) sequences that were retrieved after homology search on GenBank and on National Center for Biotechnology Information (NCBI). Primers (Table 1) for quantitative real time PCR (qPCR) experiments were designed using the NCBI Primer designing tool. 
Table 1. The set of primers used for qPCR experiments (Msactin2, MsAP2/EREB, MsNHX1, MsP5CS1, MsZFN, MsSIMKK, MsRCI2A, MsHelicase and MsbZIP)

\begin{tabular}{|c|c|c|c|}
\hline Sequence Name & Genbank Number & Primer Sequence & Amplicon Size \\
\hline Ms-actin2-F & JQ028730.1 & TTCTCACCACACTTCTCGCC & $173 b p$ \\
\hline Ms-actin2-R & & CCAGCСТTCACCATTCCAGT & \\
\hline Ms-AP2/EREB-F & Not deposited & AATGGGTGGGGAAACGGAAC & $95 b p$ \\
\hline Ms- AP2/EREB-R & & TTTGGTGGTGGAGTGTGGTT & \\
\hline Ms-NHX1-F & AY513732.1 & GCCATGAAATTCACCGACCG & $118 b p$ \\
\hline Ms-NHX1-R & & CTGCCACCAAAAACAGGACG & \\
\hline Ms- P5CS1-F & X98421.1 & TTTGCGGTCGGAAGGTGTTA & $119 b p$ \\
\hline Ms- P5CS1-R & & CGATTTCCAAGGTGCAAGCC & \\
\hline Ms-ZFN-F & JX131368.1 & CCCAAGCTGCAAGTTTGACC & $154 b p$ \\
\hline Ms-ZFN-R & & TGAGCCCGACTCAACAAGTC & \\
\hline Ms-SIMKK-F & AJ293274.1 & ACCAGAAGCTCCAACGACTG & $94 b p$ \\
\hline Ms-SIMKK-R & & CCTCGAAGCAGTCCATCTCC & \\
\hline Ms-RCI2-F & JQ665271.1 & GTTGTCAGGGGCGTCATTCT & $169 b p$ \\
\hline Ms-RCI2-R & & TCCAAGCAGGACAAAACGGA & \\
\hline Ms-Helicase-F & EF011022.1 & CCGGATCTTCAGGTTTGCCT & $131 b p$ \\
\hline Ms-Helicase-R & & TGCTTGATGCCCTCCAATGT & \\
\hline Ms-bZIP-F & HQ911778.1 & GGTGACAGTGGTTCAGAGGG & $109 b p$ \\
\hline Ms-bZIP-R & & CGTTGGCTCCATCAACAAGC & \\
\hline
\end{tabular}

Ms: Medicago sativa; AP2/EREB:apetala2/ethylene-responsive element binding; NHX1: intracellular $\mathrm{Na}^{+} / \mathrm{H}^{+}$ antiporters; P5CS1: $\triangle 1$-pyrroline-5-carboxylate synthetase 1; ZFN: Zinc Finger; SIMKK:stress-induced mitogenactivated protein kinases kinases; RCI2: rare cold inducible2A; bZIP: basic leucine zipper

\subsection{1. cDNA Synthesis and Gene Relative Expression Ratios}

Four-week-old plants were used for expression analysis. Total RNA was isolated with the Trizol isolation reagent (Invitrogen, Carlsbad, CA, USA) for reverse transcription. Both quality and quantity of nucleic acid were evaluated by agarose gel electrophoresis and NanoDrop ${ }^{\mathrm{TM}} \mathrm{UV}$, spectrophotometer respectively. The total RNA of roots and shoots was reverse-transcribed using the Superscript II enzyme (Invitrogen, Carlsbad, CA, USA), and the synthesized cDNA was used as a template in the qPCR. qPCR experiments were employed on a Step One Plus qPCR system (Applied Biosystems, Foster City, CA, USA). Samples were prepared using $10 \mu \mathrm{L}$ of Sybr Select Master Mix (Applied Biosystems, Foster City, CA, USA), $1.5 \mathrm{ng} / \mu \mathrm{L}$ cDNA as sample, $200 \mathrm{nM}$ of each primer and Molecular Biology Reagent water (Sigma) up to a final volume of $20 \mu \mathrm{L}$. For all target genes assayed the qPCR amplification thermal profile was programmed to run for 40 cycles, during which the temperature was set to be at $95^{\circ} \mathrm{C}$ for $15 \mathrm{~s}$, and at $60^{\circ} \mathrm{C}$ for $30 \mathrm{~s}$, followed by a melting curve analysis of the transcripts. Melting curves were programmed as follows: 15 seconds at $95{ }^{\circ} \mathrm{C}, 15$ seconds at $60^{\circ} \mathrm{C}, 20$ minutes' slow ramp, and 15 seconds at $95^{\circ} \mathrm{C}$. The data for the melting curve were captured during this slow ramp, and the melting curve was visualized using the Step One Plus software. Relative expression ratios were calculated according to the $2^{-\Delta \Delta \mathrm{Ct}}$ method [38]. More specifically to calculate $\Delta \Delta \mathrm{Ct}$ value, the control sample of each entry ( $M$. arborea, $M$. sativa and Alborea) was used. MS-Actin-2 was used as endogenous gene for normalization.

\subsection{Statistical Analysis}

The effect of treatment and entries on seedlings height and SER was detected by using the Repeated-Measures Analysis of Variance (ANOVA) with General Linear Model. The within-subject factors were the dates and the treatments and the between-subject factor the entries. The antioxidant capacity was estimated as the ratio of the enzymatic activity of plants under drought stress in relation to the plants under well-watered conditions. A 2-way ANOVA was used for detecting the effect of entries and organs on the ratio of the plant's enzymatic activity. Moreover, the effect of treatments, entries and organs on gene expression was detected by using a 3-way ANOVA. The Tukey test at 
0.05 probability level was chosen for detection of differences among means. The IBM SPSS Statistics 23 software (SPSS Inc., Chicago, IL, USA) was used for the statistical analysis.

\section{Results}

\subsection{The Effect of Drought Stress on Seedling Growth}

The morphological parameters (height and Stem Elongation Rate) were significantly reduced under drought stress (Table 2) compared to the control. Significant interaction for both seedling height and SER was detected between entries (M. sativa, M. arborea, Alborea) and dates of drought stress indicating a different response of the entries during the drought treatment (Figure 1a,b). Particularly, the seedlings height of Alborea's population was significantly reduced at the end of the drought treatment by about $20 \%$ (Figure 1a), while for the studied population of M. sativa and M. arborea was reduced by only $13 \%$ and $5 \%$ respectively (Figure 1a,b). However, it is noteworthy that Alborea was taller than the parental species even under drought stress (Figure 1a). Additionally, overall (across dates) the height of the parental species did not significantly differ under both control and drought stress. Similarly, the SER of Alborea's population was rapidly declined by about $98 \%$ after three weeks of water deficit, whereas the SER of population of $M$. sativa and M. arborea was gradually reduced by about $90 \%$ and $75 \%$ respectively (Figure $1 b$ ). 
Table 2. The height of seedlings, Stem Elongation Rate (SER), Relative Water Content (RWC), Photosynthetic rate (Pn), Stomatal conductance, transpiration rate (E), Water Use Efficiency (WUE) of the seedlings (mean $\pm \mathrm{SE}$ ) under the control and the drought treatment.

\begin{tabular}{|c|c|c|c|c|c|c|c|c|}
\hline & & Height (cm) & SER & RWC & $\begin{array}{l}\text { Pn }(\mu \mathrm{mol} \\
\left.\mathrm{CO}_{2} / \mathrm{m}^{2} \mathrm{~s}\right)\end{array}$ & $\begin{array}{c}\text { Gs (mol } \\
\left.\mathrm{CO}_{2} / \mathrm{m}^{2} \mathrm{~s}\right)\end{array}$ & $\begin{array}{c}\mathrm{E}(\mathrm{mmol} \\
\left.\mathrm{H}_{2} \mathrm{O} / \mathrm{m}^{2} \mathrm{~s}\right)\end{array}$ & $\begin{array}{c}\text { WUE }\left(\mu \mathrm{mol}\left(\mathrm{CO}_{2}\right)\right. \\
\mathrm{mmol}\left(\mathrm{H}_{2} \mathrm{O}\right)^{-1}\end{array}$ \\
\hline \multirow[t]{2}{*}{ Drought } & Control & $23 \pm 0.75 a *$ & $0.8 \pm 0.06 a$ & $0.9 \pm 0.09 a$ & $13.2 \pm 0.5 a$ & $0.14 \pm 0.01 \mathrm{a}$ & $1.7 \pm 0.12 \mathrm{a}$ & $8.2 \pm 0.3 b$ \\
\hline & Drought & $21 \pm 0.52 b$ & $0.4 \pm 0.04 b$ & $0.8 \pm 0.01 b$ & $9.3 \pm 0.4 b$ & $0.08 \pm 0.006 b$ & $1.0 \pm 0.08 b$ & $10.2 \pm 0.5 a$ \\
\hline \multirow[t]{3}{*}{ Entries } & M. arborea & $16 \pm 0.21 c$ & $0.3 \pm 0.03 b$ & $0.87 \pm 0.01 \mathrm{a}$ & $9.7 \pm 0.5 b$ & $0.07 \pm 0.004 b$ & $0.9 \pm 0.07 c$ & $11.1 \pm 0.50 \mathrm{a}$ \\
\hline & M. sativa & $19 \pm 0.41 b$ & $0.4 \pm 0.04 b$ & $0.85 \pm 0.01 \mathrm{a}$ & $10.6 \pm 0.5 b$ & $0.11 \pm 0.009 \mathrm{a}$ & $1.3 \pm 0.08 b$ & $8.3 \pm 0.34 b$ \\
\hline & Alborea & $31 \pm 0.77 \mathrm{a}$ & $1.0 \pm 0.09 \mathrm{a}$ & $0.8 \pm 0.02 b$ & $13.4 \pm 0.9 \mathrm{a}$ & $0.14 \pm 0.015 a$ & $1.8 \pm 0.20 \mathrm{a}$ & $8.1 \pm 0.60 \mathrm{~b}$ \\
\hline \multirow[t]{6}{*}{ Dates } & $1(20 / 11 / 15)$ & $17 \pm 0.59 \mathrm{e}$ & & & & & & \\
\hline & $2(23 / 11 / 15)$ & $20 \pm 0.78 \mathrm{~d}$ & $0.94 \pm 0.10 \mathrm{a}$ & & & & & \\
\hline & $3(26 / 11 / 15)$ & $22 \pm 1.04 c$ & $0.84 \pm 0.10 \mathrm{a}$ & $0.87 \pm 0.01 \mathrm{a}$ & $11.8 \pm 0.5 a$ & $0.11 \pm 0.008$ & $1.4 \pm 0.11$ & $9.1 \pm 0.4$ \\
\hline & $4(30 / 11 / 15)$ & $24 \pm 1.13 b c$ & $0.51 \pm 0.05 b$ & & & & & \\
\hline & $5(3 / 12 / 15)$ & $25 \pm 1.25 \mathrm{ab}$ & $0.46 \pm 0.07 \mathrm{~b}$ & $0.85 \pm 0.01 b$ & $10.7 \pm 0.7 \mathrm{~b}$ & $0.10 \pm 0.010$ & $1.3 \pm 0.14$ & $9.2 \pm 0.5$ \\
\hline & $6(7 / 12 / 15)$ & $26 \pm 1.33 a$ & $0.26 \pm 0.04 b$ & $0.8 \pm 0.02 c$ & & & & \\
\hline Source of & Drought (A) & $p<0.05$ & $p<0.05$ & $p<0.05$ & $p<0.05$ & $p<0.05$ & $p<0.05$ & $p<0.05$ \\
\hline \multirow[t]{6}{*}{ Variation } & Entries (B) & $p<0.05$ & $p<0.05$ & $p<0.05$ & $p<0.05$ & $p<0.05$ & $p<0.05$ & $p<0.05$ \\
\hline & Dates $(\mathrm{C})$ & $p<0.05$ & $p<0.05$ & $p<0.05$ & $p<0.05$ & ns & ns & ns \\
\hline & $\mathrm{AXB}$ & ns ** & $p<0.05$ & ns & $p<0.05$ & $p<0.05$ & $p<0.05$ & ns \\
\hline & $\mathrm{AXC}$ & ns & ns & $p<0.05$ & $p<0.05$ & $p<0.05$ & $p<0.05$ & ns \\
\hline & $\mathrm{BXC}$ & $p<0.05$ & $p<0.05$ & $p<0.05$ & ns & ns & ns & ns \\
\hline & $\mathrm{A} \times \mathrm{B} \times \mathrm{C}$ & ns & ns & ns & ns & ns & ns & ns \\
\hline
\end{tabular}

${ }^{*}$ Means followed by the same letter in the column for the same parameter did not significantly differ $(p>0.05)$ according to Tukey test. ${ }^{* *}$ ns: not significant at 0.05 level. 

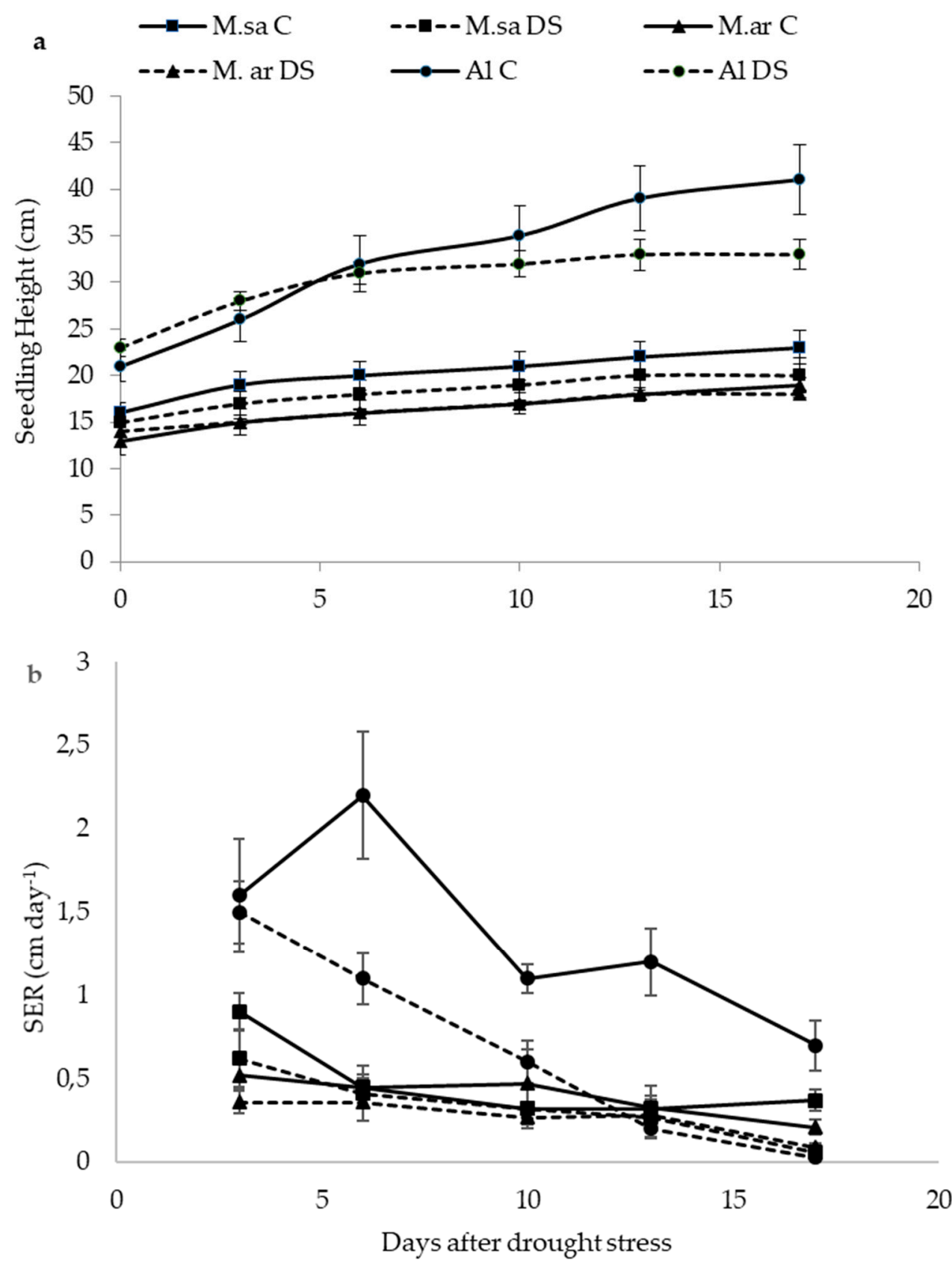

Figure 1. The seedlings height (a), and the seedlings Stem Elongation Rate (SER) (b) of M. arborea (M.ar), M. sativa (M.sa) and Alborea ( $\mathrm{Al}$ ) under control (C) and drought stress (DS) during the experimental period.Error bars indicate the mean SE.

\subsection{The Effect of Drought Stress on Physiological Parameters}

RWC and gas-exchange parameters of net photosynthetic rate (Pn), stomatal conductance (gs) and transpiration rate $(\mathrm{E})$ were significantly reduced under drought stress conditions, while the WUE increased (Table 2). Among the entries, RWC, an indicator of leaf water status was lower in the studied population of Alborea compared to population of M. sativa and M. arborea (Table 2). The RWC of Alborea's leaves was about $29 \%$ lower compared to the control after three weeks of drought stress, while the corresponding reduction of $M$. sativa and M. arborea was about $19 \%$ and $15 \%$ respectively (data not shown). The population of Alborea had the highest Pn under well-watered conditions, while after two weeks of drought stress the Pn of the entries did not significantly differ (Figure 2a). The Pn of Alborea was reduced after 1st week of water deficit but it was still higher than Pn of M. sativa and 
M. arborea. However, the Pn of M. sativa and M. arborea was significantly reduced after the 2 nd week of drought stress (Figure 2a). On the other hand, the population of M. arborea had the lowest gs and $E$ under both well-watered and water-deficit conditions, but the highest WUE (Figure 2b-d). For all the entries, the gs and E was gradually decreased after two weeks of drought stress, while the WUE increased (Figure $2 b-d$ ).

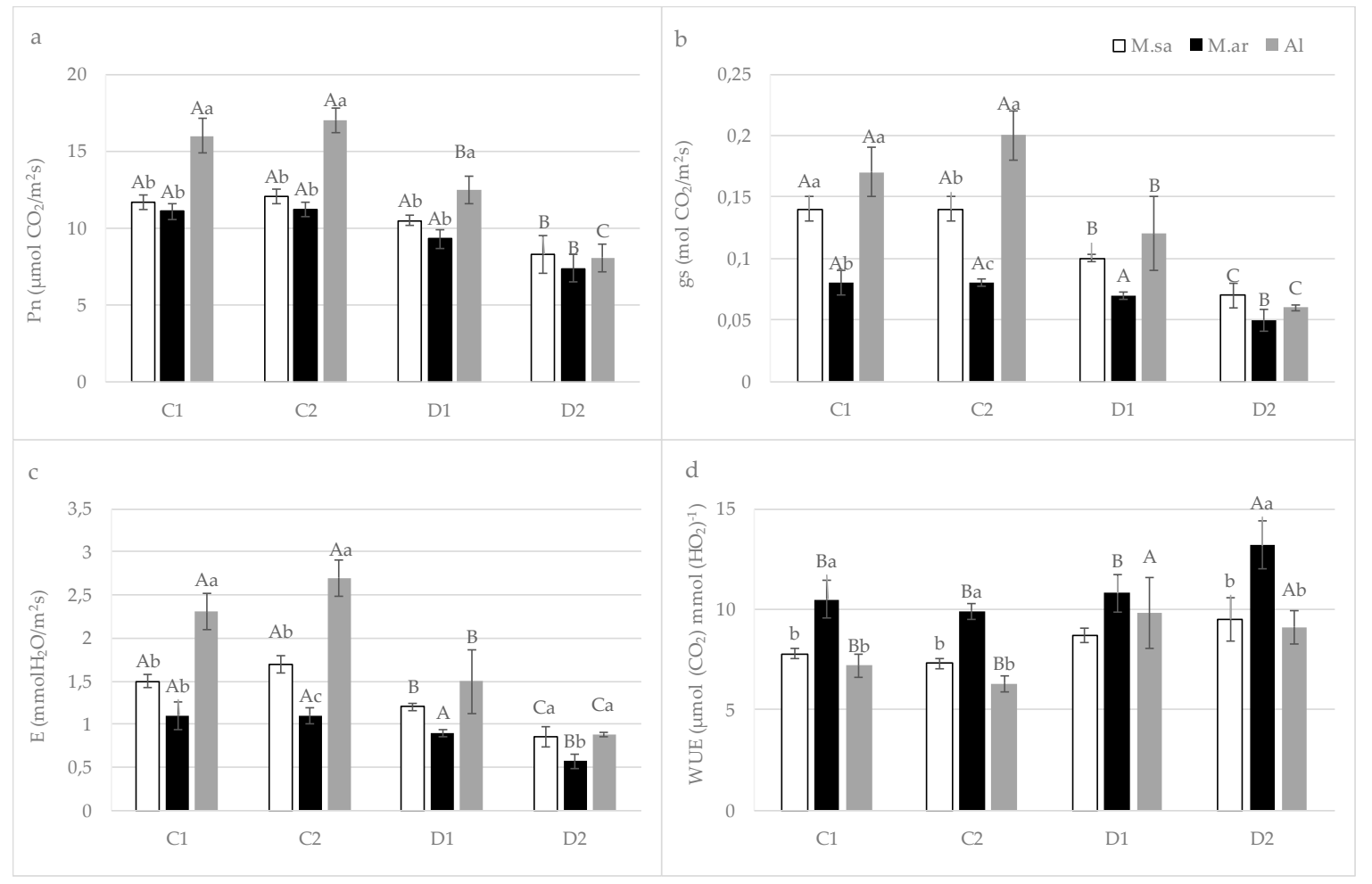

Figure 2. The net photosynthetic rate (Pn) (a), stomatal conductance (gs) (b), transpiration rate (E) (c) and Water Use Efficiency (WUE) (d) as the rate Pn/E of M. arborea (M.ar), M. sativa (M.sa) and Alborea (Al) under control (C) and drought stress (D) after the 1st (C1 and D1) and 2nd (C2 and D2) week of drought. Error bars indicate the mean \pm SE of four independent samples. The different capital letters refer to the significant differences between the same entries among the treatments (C \& D) at $p<0.05$ (Tukey test). The different small letters refer to the significant differences between the entries in the same treatment at $p<0.05$ (Tukey test).

\subsection{The Effect of Drought Stress on the Antioxidant Capacity}

Antioxidant capacity reflects the ability of plant to reduce harmful intracellular ROS concentration. ROS scavenging capacity determined by ABTS+ (2,2'-Azino-bis (3-ethylbenzothiazoline-6-sulphonic acid) increased 2.1-fold in stressed plants of $M$. sativa's population $(p<0.05)$, with significant correlation between the entries and organs. On the other hand, FRAP assays did not indicate any significant correlation between drought, entries, and organs (Table 3).

SOD activity increased in leaves and roots compared to the control, but with no statistically significant correlation. Peroxidase (POD) activity and protein content increased significantly for all the entries under drought treatment (Table 3) compared to the control, with the population of Alborea exhibiting the highest ratio in POD activity ( 1.4 fold) and of $M$. arborea the highest protein content ( 2.3 fold). Significant correlation between organs and entries was obtained in both POD activity and protein content.

Malondialdehyde (MDA) assay revealed that all the entries were prone to lipid peroxidation $(p<0.05)$ under drought stress, with leaves being more susceptible $(p<0.05)$ in comparison with roots. 
MDA content ratio shows that the population of $M$. arborea was the least susceptible under stress (Table 3).

Table 3. The ratio of the enzymatic activity of plants under drought stress in relation to the plants under well-watered conditions (mean $\pm \mathrm{SE}$ ).

\begin{tabular}{|c|c|c|c|c|c|c|}
\hline & ABTS & FRAP & SOD & POD & MDA & $\begin{array}{c}\text { Total } \\
\text { Proteins }\end{array}$ \\
\hline \multicolumn{7}{|l|}{ Entries } \\
\hline M. arborea & $1.7 \pm 0.33 \mathrm{ab}$ * & $2.4 \pm 0.4$ & $1.1 \pm 0.2$ & $0.7 \pm 0.20 b$ & $1.3 \pm 0.31 b$ & $2.3 \pm 0.2 \mathrm{a}$ \\
\hline M. sativa & $2.1 \pm 0.18 \mathrm{a}$ & $2.1 \pm 0.2$ & $0.8 \pm 0.1$ & $0.5 \pm 0.04 b$ & $1.6 \pm 0.13 \mathrm{ab}$ & $2.0 \pm 0.6 a$ \\
\hline Alborea & $1.2 \pm 0.22 b$ & $1.9 \pm 0.4$ & $1.5 \pm 0.1$ & $1.4 \pm 0.10 \mathrm{a}$ & $1.8 \pm 0.36 a$ & $0.8 \pm 0.1 b$ \\
\hline \multicolumn{7}{|l|}{ Organs } \\
\hline Leaves & $1.9 \pm 0.23 a$ & $2.0 \pm 0.3$ & $1.3 \pm 0.1$ & $0.8 \pm 0.2$ & $2.2 \pm 0.2 \mathrm{a}$ & $1.9 \pm 0.4$ \\
\hline Roots & $1.4 \pm 0.21 b$ & $2.3 \pm 0.3$ & $1.0 \pm 0.2$ & $1.2 \pm 0.1$ & $0.9 \pm 0.1 b$ & $1.4 \pm 0.3$ \\
\hline \multicolumn{7}{|l|}{$\begin{array}{l}\text { Source of } \\
\text { variation }\end{array}$} \\
\hline Entries (A) & $p<0.05$ & $\mathrm{~ns}$ & ns & $p<0.05$ & $p<0.05$ & $p<0.05$ \\
\hline Tissues (B) & $p<0.05$ & $n s$ & $n s$ & $n s$ & $p<0.05$ & $n s$ \\
\hline AXB (Interaction) & $\mathrm{ns}^{* *}$ & ns & ns & $p<0.05$ & ns & $p<0.05$ \\
\hline
\end{tabular}

\subsection{The Effect of Drought Stress on Transcriptional Responses}

The results of the ANOVA regarding the expression levels of the studied genes are presented in Table 4. Down-regulation of ZFN under drought stress was recorded for all the entries in both leaves and roots (Figure 3a,b). Other down-regulated genes under drought stress were NHX1 (leaves and roots) and bzip (roots) for M. sativa and NHX1 (roots), P5CS1 (leaves and roots) and MH1 (roots) for Alborea (Figure 3a,b). Generally, the population of M. arborea showed the highest accumulation of gene transcripts, followed by that of $M$. sativa, while the population of Alborea showed the lowest. On average, all genes examined were preferentially up-regulated in leaves compared to roots, except for SIMKK followed by P5CS1 (Figure 3a,b). In the population of M. arborea, all genes except for ZFN were highly expressed in leaves and high levels of SIMKK, P5CS1, and NHX1 transcripts were also detected in roots (Figure 3a,b). Regarding the population of $M$. sativa, it had significantly lower induction levels for all the studied genes in both leaves and roots compared to that of $M$. arborea except the $M H 1$ in roots (Figure 3a,b). However, the genes that showed profound differences in their induction levels in leaves compared to control were AP2/EREB, and P5CS1, bZIP and MH1, whereas SIMKK and $M H 1$ were highly induced in roots. Finally, in Alborea, minor differences in expression levels compared to control were recorded in leaves for the studied genes and only AP2/EREB transcripts was highly abundant in roots (Figure $3 \mathrm{a}, \mathrm{b}$ ).

The heat map was based on gene expression levels of the examined genes. All gene expression levels were colored black, dark gray or gray to represent high, moderate, and low expression ratio respectively (Figure 4). As highlighted in the figure, Alborea exhibited the lowest induction of all genes. Furthermore, the most pronounced differences in gene expression between control and drought stressed plants were recorded for $A P 2 / E R E B$ gene. 
Table 4. The effect of drought stress, species, and tissue on genes expression (mean $\pm \mathrm{SE}$ )

\begin{tabular}{ccccccccc}
\hline & AREB & bZIP & P5CS1 & ZFG & NHX & MH1 & SIMKK & RCI2A \\
\hline Source of variation & & & & & & & & \\
Drought (A) & $p<0.05$ & $p<0.05$ & $p<0.05$ & $p<0.05$ & $p<0.05$ & $p<0.05$ & $p<0.05$ & $p<0.05$ \\
Entries (B) & $p<0.05$ & $p<0.05$ & $p<0.05$ & ns & $p<0.05$ & $p<0.05$ & $p<0.05$ & $p<0.05$ \\
Organs (C) & $p<0.05$ & $p<0.05$ & ns & $p<0.05$ & $p<0.05$ & ns & ns & $p<0.05$ \\
AXB (Interaction) & $p<0.05$ & $p<0.05$ & $p<0.05$ & ns & $p<0.05$ & $p<0.05$ & $p<0.05$ & $p<0.05$ \\
AXC (Interaction) & $p<0.05$ & $p<0.05$ & ns & $p<0.05$ & ns & ns & ns & $p<0.05$ \\
BXC (Interaction) & $p<0.05$ & $p<0.05$ & ns & ns & $p<0.05$ & $p<0.05$ & $p<0.05$ & $p<0.05$ \\
AXBXC(Interaction) & $p<0.05$ & $p<0.05$ & ns & ns & ns & $p<0.05$ & $p<0.05$ & $p<0.05$ \\
\hline
\end{tabular}

AP2/EREB:apetala2/ethylene-responsive element binding; NHX1:intracellular $\mathrm{Na}^{+} / \mathrm{H}^{+}$antiporters; P5CS1: 1 1-pyrroline5-carboxylate synthetase 1; ZFN:Zinc Finger; SIMKK:stress-induced mitogen-activated protein kinases kinases; RCI2:rare cold inducible2A; bZIP:basic leucine zipper; MH1:Medicago sativa Helicase 1. * n.s not significant.

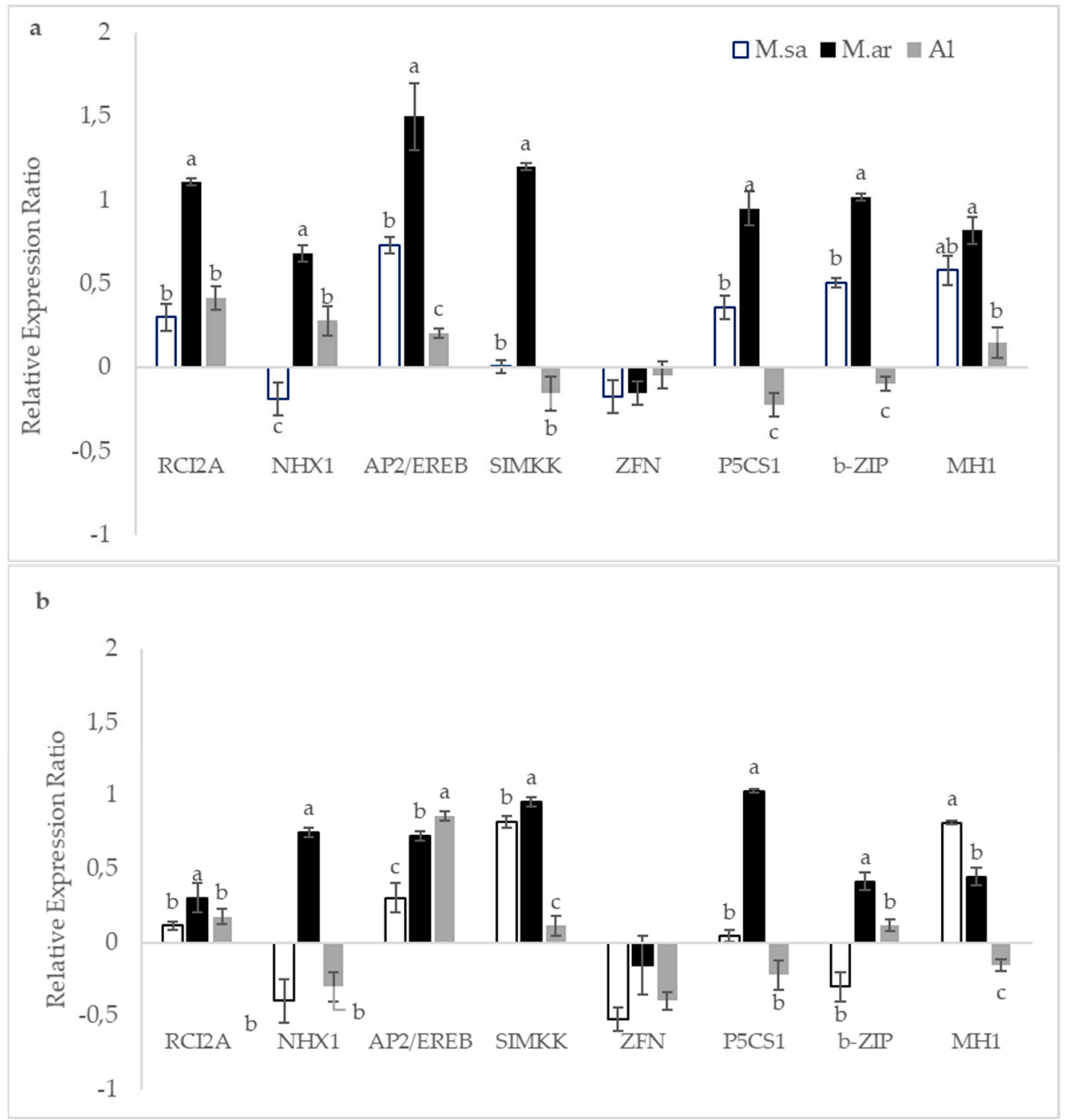

Figure 3. RCI2A, NHX1, AP2/EREB, SIMKK, ZFN, P5CS1, bzip, and MH1 relative expression level for $M$. arborea (M.ar), M. sativa (M.sa) and Alborea (Al) under drought stress for leaves (a) and roots (b). Error bars indicate the mean $\pm \mathrm{SE}$. The different small letters refer to the significant differences between the entries in the same treatment at $p<0.05$ (Tukey test). Relative expression ratios were calculated according to the $2^{-\Delta \Delta C t}$ method. More specifically to calculate $\Delta \Delta C \mathrm{t}$ value, the control sample of each entry (M. arborea, M. sativa and Alborea) was used. MS-Actin-2 was the endogenous gene used for normalization. 


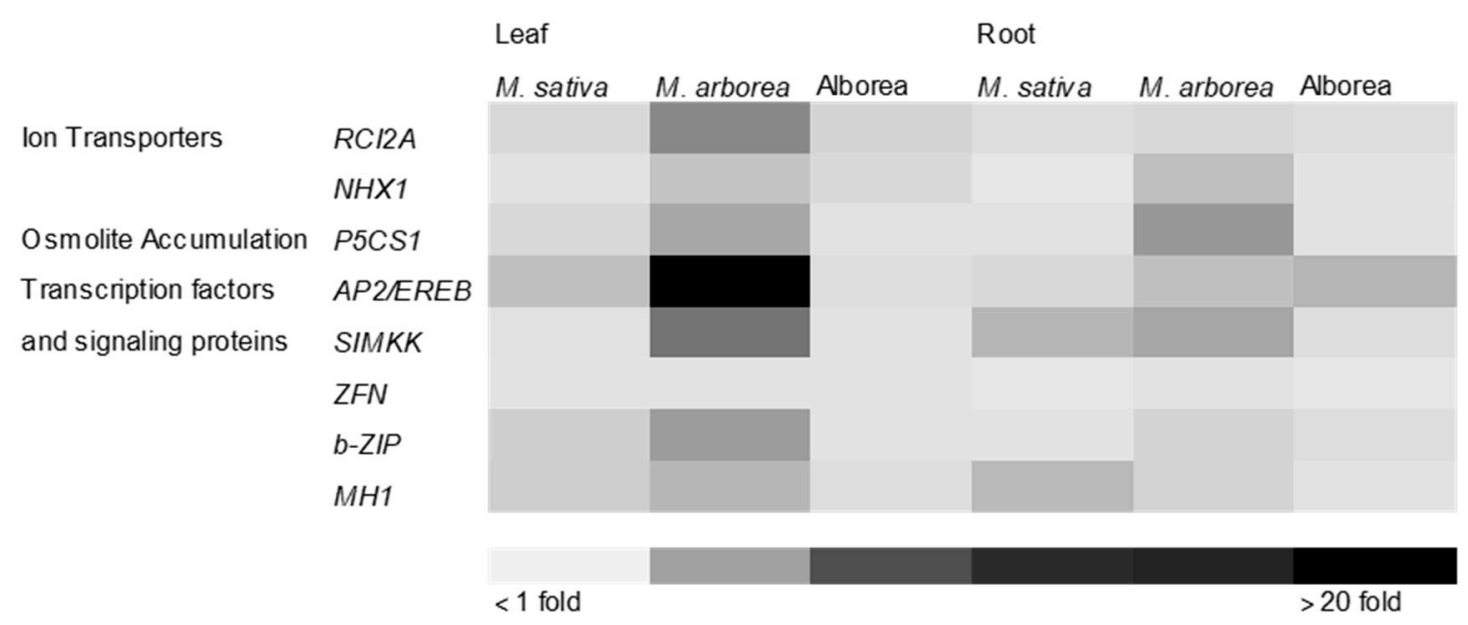

Figure 4. General expression level of RCI2A, NHX1, AP2/EREB, SIMKK, ZFN, bZIP, MH1 and P5CS1 under drought treatments for M. arborea, M. sativa and Alborea. Expression levels are black and gray-coded to depict the fold change as follows: black (high expression level $>20$-fold) to gray (low $<1$-fold).

\section{Discussion}

\subsection{Seedling Growth and Physiological Responses under Drought Stress}

Drought is the major threat for the productivity of fodder crops in the Mediterranean area. The water deficit results in the reduction of seedling growth, which is a critical factor for plant productivity [39]. According to the results of the present study, the seedlings' height and the stem elongation rate of $M$. sativa, $M$. arborea and their hybrid was reduced under drought conditions which is consistent with many other studies [40], including medicagos [41-43]. The inhibition of stem elongation decreases the demand for metabolites and allows the plants to synthesize protective compounds for osmotic adjustment [44].

The hybrid, which had remarkably higher stem elongation rates compared to the parent species under well-watered conditions, exhibited the most dramatic reduction under drought stress. Similar results have been reported by Clifton-Brown and Lewandowski [45] for Miscanthus $x$ giganteus, a sterile hybrid of M. sacchariflorus and M. sinensis parentage [40], which is highly productive but less drought-tolerant compared to its parent species.

The leaf RWC is considered an essential indicator of water status in plants, signifying the balance between water supply and transpiration rate in leaf tissue [46] and is a meaningful determinant of plants' drought tolerance. In this regard, the studied population of $M$. arborea maintains a better water status than that of M. sativa and Alborea, which is critical for its physiological functioning and survival under drought. The decrease in RWC in plants with low tolerance against drought was observed in many species and has been accompanied with plant vigor reduction [47].

Stomatal closure is considered to be an early plant response to drought that allows RWC maintenance $[48,49]$ and consequently reduces photosynthesis [50,51]. In the present study, the most profound decline of gs was observed in the population of Alborea followed by that of M. sativa in drought conditions that was simultaneously accompanied with a reduction in Pn. Nevertheless, Alborea had higher Pn than the parental species the first week of drought stress. On the other hand, the population of M. arborea that was characterized by a lower Pn and gs under well-watered conditions, preserved similar rates under water-deficit conditions. The lowest reduction of Pn, E and gs found in population of $M$. arborea between control and stressed plants may play a critical role in its better adaptive responses to decreased water supply.

It is well documented that higher WUE species can be better adapted to drought. The increase in WUE under water deficit is generally attributed to the following: a. the water use is reduced more than 
biomass production [52] or $\mathrm{b}$. transpiration rate decreased more than net $\mathrm{CO}_{2}$ assimilation rate [53]. According to our results the higher WUE was recorded for the population of $M$. arborea under drought stress and this could be a consequence of lower decrease of Pn rate compared to the decrease of $E$ rate.

On the other hand, the strategy of Alborea's and M. sativa's population under drought was to sharply drop Pn. This can be advantageous under short periods of severe drought stress but could have a negative impact when drought stress is imposed for long periods. Under the latter conditions, the strategy of M. arborea's population (gradual reduction in Pn) could be more efficient.

It must be mentioned that the population of Alborea had the highest Pn under well-water conditions and that of $M$. arborea the lowest. In general, high Pn contribute to high growth rates. Nevertheless, the growth rate also depends on nutrient availability and on the genetic potential [54]. Our results confirm the hypothesis that slow growing species such as M. arborea that permit conservation of resources (conservative strategy) are better adapted to environmental stresses compared to species (Alborea) that allow rapid acquisition of resources (acquisitive strategy) $[55,56]$.

\subsection{Drought Stress and Antioxidant Capacity}

One of the plant's first response to environmental stressors (abiotic and/or biotic), is the production of ROS, that functions as a signal to molecules in the complex network of a plant's stress response mechanism [10,57-59]. However, continuous stress can cause an accumulation of ROS at the plasma membrane, and subsequent cell damage. Thus, the generation of ROS requires the up-regulation of antioxidant/detoxifying systems such as SOD and POD [60]. In the present study, no significant increase of SOD activity was observed while a substantial increase was measured for POD for all the entries.

As previously mentioned, accumulation of ROS can cause increase of membrane lipid peroxidation leading to high levels of MDA, which is used as an indicator of oxidative damage [18,61,62]. Moreover, ROS generation inhibits protein synthesis or provokes protein denaturation [63].

Compared to the population of Alborea, the population of M. arborea and M. sativa exhibited lower levels of lipid peroxidation (MDA content), higher protein content as well as higher non-enzymatic antioxidant capacity. These observations suggest that these species acquire a more efficient protective mechanism against oxidative damage than their hybrid (Alborea). Several reports have demonstrated that tolerant genotypes have a high ability to circumvent drought stress due to lower lipid peroxidation, better antioxidant capacity $[64,65]$ and high protein content [63].

\subsection{Drought Stress and Transcriptional Responses}

In the present study, we examined the transcriptional profile of eight stress -related genes under drought conditions (AP2/EREB, ZFN, bZIP, NHX1, RCI2A, MH1, SIMKK and P5CS1). Special attention was given to the role of the aforementioned genes to enhanced antioxidant capacity, protein protection and membrane stability.

The ion transporters NHX1 and RCI2A genes are induced by several environmental factors that decrease the availability of water such as chilling, salt, pathogen attack and obviously water stress [66,67]. They function as membrane stabilizers by controlling the uptake of cations and/or the efflux of anions. They also affect the cellular $\mathrm{pH}$ and subsequently, the cellular ROS levels, cell membrane homeostasis and enhanced ROS scavenging [68]. Expression of RCI2A in transgenic tomato enhanced cold tolerance by upregulating the activity of peroxidase and ascorbate peroxidase (APX) by conferring better antioxidant capacity, reduced lipid peroxidation, and ultimately reduced membrane damage [68]. Our results show elevated transcript levels of NHX1 in both leaves and roots and profound up-regulation of $R C I 2 A$ gene in leaves of the studied population of $M$. arborea, which possibly causes enhanced protection against cell damage and preserved cell membrane integrity possibly by better antioxidant capacity.

The P5CS1 gene encodes a key component in proline biosynthesis and accumulation. Many studies have highlighted the positive correlation of proline accumulation with adaptability of plants in 
response to several stresses such as drought and salt stress [69-71]. Greatly higher expression of P5CS1, especially in roots, has been detected in the population of $M$. arborea compared to that of $M$. sativa and Alborea. Moreover, a down-regulation of P5CS1 was monitored in roots of Alboreasubjected to drought stress compared to the control. As several studies have highlighted the role of proline as an osmoprotectant and free-radicals scavenger, it can be assumed that the population of $M$. arborea and to a lesser extent the population of $M$. sativa have a better antioxidant capacity than that of Alborea in order to protect protein integrity and to gain plant tolerance to drought stress [72,73].

Since bzip transcription factors are directly activated by the ABA-dependent pathway, in many cases they improve plant tolerance to both salt and drought stresses [74,75]. The same studies reported that usually bzip transcription factors form complexes with other transcription factors (such as $M y b$ or $A P 2 / E R E B)$, acting together to activate ABA-responsive genes or to bind to promoters of other defense related genes (i.e., NHX1). Additionally, both AP2/EREB transcription factors and ZFNs are involved in many aspects of abiotic and biotic stress responses [76-78]. The population of $M$. arborea exhibited the highest induction of bzip transcription factor in both leaves and roots indicating that it is involved in its drought tolerance. On the other hand, the high induction of an AP2/EREB transcription factor belonging to the AINTEGUMENTA subgroup [24] highlights its importance regarding the response of the studied populations to drought stress. It is noteworthy that AINTEGUMENTA gene was the only gene that was highly expressed in roots of Alborea's population. Interestingly, the transcript levels of ZFN were less abundant in the stressed plants in comparison to controls. These findings agree with only one report that correlated the down-regulation of a ZFN protein (namely DST- Drought and Salt Tolerance) with the better drought and salt tolerance thought regulation of $\mathrm{H}_{2} \mathrm{O}_{2}$ homeostasis [79].

The involvement of mitogen-activated protein kinases (MAPK) in plants adaptation to salt and drought has been highlighted for a plethora of plant species including rice, Arabidopsis and $M$. sativa [80-82]. In many instances they play an important role in abiotic oxidative stress responses and ROS metabolism [83]. Consistent with previous results, drought stress led to higher expression levels of SIMKK gene (stress-induced MAPK) in both leaves and roots of the studied population of $M$. arborea in both leaves and roots and of $M$. sativa in roots, indicating that it might regulate the antioxidant defense system of both species in response to stress signaling.

The adaptive strategy of plants stress tolerance has implicated the involvement of helicases in many cases [26]. Shivakumara et al. [84] demonstrated that even a single helicase gene can impart tolerance to multiple stresses in chili plants (Capsicum annuum) via reduction of photo-oxidative damage and reduced production of ROS and by enhancing or stabilizing protein synthesis. In the present study, MH1 was the only gene that its induction under drought stress was higher in roots of $M$. sativa's population compared to that of M. arborea, while it was similar in leaves of the two species. This further supports the MH1 involvement in drought tolerance possible by rendering a better protection against ROS production.

\section{Conclusions}

As mentioned by several researchers, hybrid vigor greatly depends on its increased photosynthetic efficiency [85-87]. Moreover, the increased growth of hybrids and their tolerance to stressful environments act in an antagonistic manner. This is the case with the hybrid in the present study as well. When drought occurs, the hybrid suffers high water losses that cannot be compensated even by early stomatal closure. After stomatal closure, Alborea seems to be unable to synthesize energetically rich compounds that are essential for biosynthetic processes. On the other hand, M. arborea, which has lower Pn in well-watered and stressful conditions, does not have to limit its metabolic processes, thus it can increase the efficiency of protective systems. Several other studies have indicated that hybrids with increased drought tolerance also exhibited lesser changes of Pn and gs in water-deficit conditions compared to drought-sensitive hybrids and up-regulated ROS scavengers $[65,88]$.

Moreover, genes that could possibly lead to higher antioxidant capacity, membrane integrity and protein stability such as RCI2A, MH1, NHX1, P5CS1, SIMKK, were also up-regulated in M. arborea 
and to a lesser extent in M. sativa. Both parents showed better antioxidant capacity than Alborea thus they perform better than Alborea under drought conditions. Among the studied genes an AP2/EREB transcription factor belonging to the AINTEGUMENTA subgroup seems to be key player for the response of the studied populations to drought stress. Similar results were obtained from the study of the same population of the species under salt shock and stress [24]. Further research on the contribution of AINTEGUMENTA gene to abiotic tolerance is needed as there are only a few studies regarding its role to both salt and drought tolerance.

According to the results, it seems that the parental species and especially M. arborea are more tolerant that their hybrid to drought. The fact that Alborea is a high yielding hybrid, with high photosynthetic rates and high biomass, probably affects its drought sensitivity. Consequently, the ability to offer some yield protection in the high yielding hybrid Alborea in higher stress environments yet not sacrifice yield potential in low stress/high yield potential environments should be further explored by improving traits such as stability of leaf gas-exchange parameters and antioxidant capacity.

Author Contributions: Conceptualization, E.T. and E.M.A.; Methodology, E.T., N.E.L., M.P and E.M.A; Formal Analysis, E.M.A.; Investigation, E.S., M.G., X.V., A.T., E.G.C., and M.P.; Data Curation, E.S. and E.G.C. Writing-Original Draft Preparation, E.T., E.G.C. and E.M.A.; Writing-Review \& Editing, N.L.; Visualization, E.M.A.; Supervision, E.T., N.E.L. and E.M.A; Project Administration, E.T. and E.M.A; Funding Acquisition, P.J.B.

Funding: This research received no external funding.

Acknowledgments: We would like to thank Antonia Tzampazy (native English speaker) for carefully reading and correcting our manuscript.

Conflicts of Interest: The authors declare no conflict of interest.

\section{References}

1. Valliyodan, B.; Nguyen, H.T. Understanding regulatory networks and engineering for enhanced drought tolerance in plants. Curr. Opin. Plant Biol. 2006, 9, 189-195. [CrossRef] [PubMed]

2. Reguera, M.; Peleg, Z.; Blumwald, E. Targeting metabolic pathways for genetic engineering abiotic stresstolerance in crops. Biochim. Biophys. Acta (BBA) Gene Regul. Mech. 2012, 1819, 186-194. [CrossRef] [PubMed]

3. Osakabe, Y.; Osakabe, K.; Shinozaki, K.; Tran, L.-S.P. Response of plants to water stress. Front. Plant Sci. 2014, 5, 86. [CrossRef] [PubMed]

4. Krasensky, J.; Jonak, C. Drought, salt, and temperature stress-induced metabolic rearrangements and regulatory networks. J. Exp. Bot. 2012, 63, 1593-1608. [CrossRef] [PubMed]

5. Pinheiro, C.; Chaves, M.M. Photosynthesis and drought: Can we make metabolic connections from available data? J. Exp. Bot. 2011, 62, 869-882. [CrossRef] [PubMed]

6. Anjum, S.A.; Ashraf, U.; Tanveer, M.; Khan, I.; Hussain, S.; Shahzad, B.; Zohaib, A.; Abbas, F.; Saleem, M.F.; Ali, I.; et al. Drought induced changes in growth, osmolyte accumulation and antioxidant metabolism of three maize hybrids. Front. Plant Sci. 2017, 8, 69. [CrossRef] [PubMed]

7. Anjum, S.A.; Wang, L.; Farooq, M.; Xue, L.; Ali, S. Fulvic acid application improves the maize performance under well-watered and drought conditions. J. Agron. CropSci. 2011, 197, 409-417. [CrossRef]

8. Anjum, S.A.; Wang, L.C.; Farooq, M.; Hussain, M.; Xue, L.L.; Zou, C.M. Brassinolide application improves the drought tolerance in maize through modulation of enzymatic antioxidants and leaf gas exchange. J. Agron. CropSci. 2011, 197, 177-185. [CrossRef]

9. Ashraf, U.; Kanu, A.S.; Mo, Z.; Hussain, S.; Anjum, S.A.; Khan, I.; Abbas, R.N.; Tang, X. Lead toxicity in rice: Effects, mechanisms, and mitigation strategies-A mini review. Environ. Sci. Pollut. Res. Int. 2015, 22, 18318-18332. [CrossRef]

10. Sharma, P.; Jha, A.B.; Dubey, R.S.; Pessarakli, M. Reactive oxygen species, oxidative damage, and antioxidative defense mechanism in plants under stressful conditions. J. Bot. 2012, 2012, 217037. [CrossRef]

11. Adebayo, M.A.; Menkir, A. Assessment of hybrids of drought tolerant maize (Zea mays L.) inbred lines for grain yield and other traits under stress managed conditions. Niger. J. Genet. 2014, 28, 19-23. [CrossRef]

12. Farooq, M.; Wahid, A.; Kobayashi, N.; Fujita, D.; Basra, S.M.A. Plant drought stress: Effects, mechanisms and management. Agron. Sustain. Dev. 2009, 29, 185-212. [CrossRef] 
13. Ramanjulu, S.; Bartels, D. Drought- and desiccation-induced modulation of gene expression in plants. Plant Cell Environ. 2002, 25, 141-151. [CrossRef] [PubMed]

14. Sreenivasulu, N.; Sopory, S.K.; KaviKishor, P.B. Deciphering the regulatory mechanisms of abiotic stress tolerance in plants by genomic approaches. Gene 2007, 388, 1-13. [CrossRef] [PubMed]

15. Moran, M.S.; Clarke, T.R.; Inoue, Y.; Vidal, A. Estimating crop water deficit using the relation between surface-air temperature and spectral vegetation index. Remote. Sens. Environ. 1994, 49, 246-263. [CrossRef]

16. Bhattarai, K.; Brummer, E.C.; Monteros, M.J. Alfalfa as a bioenergy crop. In Bioenergy Feedstocks: Breeding and Genetics; Saha, M.C., Bhandari, H.S., Bouton, J.H., Eds.; Wiley: New York, NY, USA, 2013; pp. 207-231. ISBN 9780470960332.

17. Tang, L.L.; Cai, H.; Ji, W.; Luo, X.; Wang, Z.Y.; Wu, J.; Wang, X.D.; Cui, L.; Wang, Y.; Zhu, Y.M.; et al. Overexpression of GsZFP1 enhances salt and drought tolerance in transgenic alfalfa (Medicago sativa L.). Plant Physiol. Biochem. 2013, 71, 22-30. [CrossRef] [PubMed]

18. Zhang, H.; Liu, Y.; Wen, F.; Yao, D.; Wang, L.; Guo, J.; Ni, L.; Zhang, A.; Tan, M.; Jiang, M. A novel rice $\mathrm{C} 2 \mathrm{H} 2$-type zinc finger protein, ZFP36, is a key player involved in abscisic acid-induced antioxidant defense and oxidative stress tolerance in rice. J. Exp. Bot. 2014, 65, 5795-5809. [CrossRef]

19. Quan, W.; Liu, X.; Wang, H.; Chan, Z. Comparative physiological and transcriptional analyses of two contrasting drought tolerant alfalfa varieties. Front. Plant Sci. 2015, 6, 1256. [CrossRef]

20. Wu, S.; Ning, F.; Zhang, Q.; Wu, X.; Wang, W. Enhancingomics research of crop responses to drought under field conditions. Front. Plant Sci. 2017, 8, 174.

21. Noitsakis, B.; Radoglou, K.M.; Jarvis, P.G. Water relation and growth in two years old seedlings of Medicagoarborea under short-time water stress. PhytonAnn. Rei Bot. 1991, 31, 111-120.

22. Bingham, E.T.; Armour, D.; Irwin, J.A.G. The hybridization barrier between herbaceous Medicago sativa and woody M. arborea is weakened by selection of seed parents. Plants 2013, 2, 343-353. [CrossRef] [PubMed]

23. Irwin, J.A.G.; Sewell, J.C.; Woodfield, D.R.; Bingham, E.T. Restructuring lucerne (Medicago sativa) through introgression of the Medicagoarborea genome. Agric. Sci. 2016, 28, 40-46.

24. Tani, E.; Sarri, E.; Goufa, M.; Asimakopoulou, G.; Psychogiou, M.; Bingham, E.; Skaracis, G.; Abraham, E. Seedling growth and transcriptional responses to salt shock and stress in Medicago sativa L., Medicagoarborea L., and their hybrid (Alborea). Agronomy 2018, 8, 231. [CrossRef]

25. Forni, C.; Duca, D.; Glick, B.R. Mechanisms of plant response to salt and drought stress and their alteration by rhizobacteria. Plant Soil 2017, 410, 335-356. [CrossRef]

26. Luo, Y.; Liu, Y.B.; Dong, Y.X.; Gao, X.-Q.; Zhang, X.S. Expression of a putative alfalfa helicase increases tolerance to abiotic stress in arabidopsis by enhancing the capacities for ros scavenging and osmotic adjustment. J. Plant Physiol. 2009, 166, 385-394. [CrossRef] [PubMed]

27. Li, Y.; Sun, Y.; Yang, Q.; Fang, F.; Kang, J.; Zhang, T. Isolation and characterization of a gene from Medicago sativa L., encoding a bZIP transcription factor. Mol. Biol. Rep. 2013, 40, 1227-1239. [CrossRef] [PubMed]

28. Suh, A. Evaluation of Bioactivity of Phytotoxins from Pathogenic Fungi of Orobanche sp. Ph.D. Thesis, Argicultural University of Athens, Athens Greece, 2011.

29. Barrs, H.; Weatherley, P. A re-examination of the relative turgidity technique for estimating water deficits in leaves. Aust. J. Biol. Sci. 1962, 15, 413-428. [CrossRef]

30. Benzie, I.F.F.; Strain, J.J. The ferric reducing ability of plasma (frap) as a measure of "antioxidant power": The frap assay. Anal. Biochem. 1996, 239, 70-76. [CrossRef]

31. Pellegrini, N.; Serafini, M.; Colombi, B.; Del Rio, D.; Salvatore, S.; Bianchi, M.; Brighenti, F. Total antioxidant capacity of plant foods, beverages and oils consumed in Italy assessed by three different in vitro assays. J. Nutr. 2003, 133, 2812-2819. [CrossRef]

32. Li, X.; Luo, Y.; Shen, H.; You, J. Antioxidant activities and functional properties of grass carp (Ctenopharyngodonidellus) protein hydrolysates. J. Sci. Food Agric. 2012, 92, 292-298. [CrossRef]

33. Stewart, R.R.C.; Bewley, J.D. Lipid peroxidation associated with accelerated aging of soybean axes. Plant Physiol. 1980, 65, 245-248. [CrossRef] [PubMed]

34. Hodges, D.M.; DeLong, J.M.; Forney, C.F.; Prange, R.K. Improving the thiobarbituric acid-reactive-substances assay for estimating lipid peroxidation in plant tissues containing anthocyanin and other interfering compounds. Planta 1999, 207, 604-611. [CrossRef] 
35. McCord, J.M.; Fridovich, I. Superoxide dismutase: An enzymic function for erythrocuprein (hemocuprein). J. Biol. Chem. 1969, 244, 6049-6055. [PubMed]

36. Polle, A.; Otter, T.; Seifert, F. Apoplastic peroxidases and lignification in needles of Norway spruce (Piceaabies L.). Plant Physiol. 1994, 106, 53-60. [CrossRef] [PubMed]

37. Bradford, M.M. A rapid and sensitive method for the quantitation of microgram quantities of protein utilizing the principle of protein-dye binding. Anal. Biochem. 1976, 72, 248-254. [CrossRef]

38. Livak, K.J.; Schmittgen, T.D. Analysis of relative gene expression data using real-time quantitative pcr and the $2^{-\triangle \Delta C T}$ method. Methods 2001, 25, 402-408. [CrossRef] [PubMed]

39. Kashif, M. Performance of wheat genotypes under osmotic stress at germination and early seedling growth stage. Sky J. Agric. Res. 2013, 2, 116-119.

40. Ings, J.; Mur, L.A.J.; Robson, P.R.H.; Bosch, M. Physiological and growth responses to water deficit in the bioenergy crop Miscanthus x giganteus. Front. Plant Sci. 2013, 4, 468. [CrossRef]

41. Mouradi, M.; Farissi, M.; Bouizgaren, A.; MAKOUDI, B.; Kabbadj, A.; Véry, A.-A.; Sentenac, H.; Qaddourya, A.; Ghoulam, C. Effects of water deficit on growth, nodulation and physiological and biochemical processes in Medicago sativa-rhizobia symbiotic association. Arid. Land Res. Manag. 2016, 30, 193-208. [CrossRef]

42. Benjamin, J.G.; Nielsen, D.C.; Vigil, M.F.; Mikha, M.M.; Calderon, F. Water deficit stress effects on corn (Zea mays L.) root:shoot ratio. Open J. Soil Sci. 2014, 4, 10. [CrossRef]

43. Zhang, C.; Shi, S.; Wang, B.; Zhao, J. Physiological and biochemical changes in different drought-tolerant alfalfa (Medicago sativa L.) varieties under PEG-induced drought stress. Acta Physiol. Plant. 2018, 40, 25. [CrossRef]

44. Chaves, M.M.; Maroco, J.P.; Periera, S. Understanding plant responses to drought-From genes to the whole plant. Funct. Plant Biol. 2003, 30, 239-264. [CrossRef]

45. Clifton-Brown, J.C.; Lewandowski, I. Water use efficiency and biomass partitioning of three different miscanthus genotypes with limited and unlimited water supply. Ann. Bot. 2000, 86, 191-200. [CrossRef]

46. Lugojan, C.; Ciulca, S. Evaluation of relative water content in winter wheat. J. Hortic. For. Biotechnol. 2011, $15,173-177$.

47. Hassanzadeh, M.; Ebadi, A.; Panahyan-e-Kivi, M.G.; Eshghi, A.; Jamaati-e-Somarin, S.; Saeidi, M.; Zabihi-e-Mahmoodabad, R. Evaluation of drought stress on relative water content and chlorophyll content of sesame (Sesamumindicum L.) genotypes at early flowering stage. Res. J. Environ. Sci. 2009, 3, 345-350. [CrossRef]

48. Jia, W.; Zhang, J. Stomatal movements and long-distance signaling in plants. Plant Signal. Behav. 2008, 3, 772-777. [CrossRef]

49. Harb, A.; Krishnan, A.; Ambavaram, M.M.R.; Pereira, A. Molecular and physiological analysis of drought stress in arabidopsis reveals early responses leading to acclimation in plant growth. Plant Physiol. 2010, 154, 1254-1271. [CrossRef]

50. Galmés, J.; Flexas, J.; Savé, R.; Medrano, H. Water relations and stomatal characteristics of mediterranean plants with different growth forms and leaf habits: Responses to water stress and recovery. Plant Soil 2007, 290, 139-155. [CrossRef]

51. Bousba, R.; Ykhlef, N.; Djekoun, A. Water use efficiency and flat leaf photosynthetic in response to water deficit of durum wheat (Triticum durum desf). WJAS 2009, 5, 609-616.

52. Bramley, H.; Turner, N.C.; Turner, D.W.; Tyerman, S.D. Roles of morphology, anatomy, and aquaporins in determining contrasting hydraulic behavior of roots. Plant Physiol. 2009, 150, 348-364. [CrossRef]

53. Bacelar, E.A.; Moutinho-Pereira, J.M.; Gonçalves, B.C.; Ferreira, H.F.; Correia, C.M. Changes in growth, gas exchange, xylem hydraulic properties and water use efficiency of three olive cultivars under contrasting water availability regimes. Environ. Exp. Bot. 2007, 60, 183-192. [CrossRef]

54. Kirschbaum, M.U.F. Does enhanced photosynthesis enhance growth? Lessons learned from $\mathrm{CO}_{2}$ enrichment studies. Plant Physiol. 2011, 155, 117-124. [CrossRef] [PubMed]

55. Ouédraogo, D.Y.; Mortier, F.; Gourlet-Fleury, S.; Freycon, V.; Picard, N.; Turnbull, M. Slow-growing species cope best with drought: Evidence from long-term measurements in a tropical semi-deciduous moist forest of central Africa. J. Ecol. 2013, 101, 1459-1470. [CrossRef]

56. Zhou, Z.; Su, P.; González-Paleo, L.; Xie, T.; Li, S.; Zhang, H. Trade-off between leaf turnover and biochemical responses related to drought tolerance in desert woody plants. J. Arid. Environ. 2014, 103, 107-113. [CrossRef] 
57. You, J.; Chan, Z. ROS regulation during abiotic stress responses in crop plants. Front. Plant Sci. 2015, 6, 1092. [CrossRef] [PubMed]

58. Foyer, C.H.; Noctor, G. Oxidant and antioxidant signalling in plants: A re-evaluation of the concept of oxidative stress in a physiological context. Plant Cell Environ. 2005, 28, 1056-1071. [CrossRef]

59. Mittler, R.; Vanderauwera, S.; Gollery, M.; Van Breusegem, F. Reactive oxygen gene network of plants. Trends Plant Sci. 2004, 9, 490-498. [CrossRef]

60. Gill, S.S.; Tuteja, N. Reactive oxygen species and antioxidant machinery in abiotic stress tolerance in crop plants. Plant Physiol. Biochem. 2010, 48, 909-930. [CrossRef]

61. Hasanuzzaman, M.; Nahar, K.; Fujita, M. Extreme temperature responses, oxidative stress and antioxidant defense in plants. In Abiotic Stress-Plant Responses and Applications in Agriculture; Vahdati, D.K., Ed.; InTech: London, UK, 2013; pp. 169-205.

62. Choudhury, F.K.; Rivero, R.M.; Blumwald, E.; Mittler, R. Reactive oxygen species, abiotic stress and stress combination. Plant J. 2017, 90, 856-867. [CrossRef]

63. Fazeli, F.; Ghorbanli, M.; Niknam, V. Effect of drought on biomass, protein content, lipid peroxidation and antioxidant enzymes in two sesame cultivars. Biol. Plant. 2007, 51, 98-103. [CrossRef]

64. Ren, S.; Lyle, C.; Jiang, G.-L.; Penumala, A. Soybean salt tolerance 1 (GmST1) reduces ROS production, enhances aba sensitivity, and abiotic stress tolerance in Arabidopsis thaliana. Front. Plant Sci. 2016, 7, 445. [CrossRef] [PubMed]

65. Avramova, V.; AbdElgawad, H.; Vasileva, I.; Petrova, A.S.; Holek, A.; Mariën, J.; Asard, H.; Beemster, G.T.S. High antioxidant activity facilitates maintenance of cell division in leaves of drought tolerant maize hybrids. Front. Plant Sci. 2017, 8, 84. [CrossRef] [PubMed]

66. Navarre, C.; Goffeau, A. Membrane hyperpolarization and salt sensitivity induced by PMP3 a highly conserved small protein of yeast plasma membrane. EMBO J. 2000, 19, 2515-2524. [CrossRef] [PubMed]

67. Nylander, M.; Heino, P.; Helenius, E.; TapioPalva, E.; Ronne, H.; Welin, B.V. The low-temperature- and salt-induced RCI2A gene of arabidopsis complements the sodium sensitivity caused by a deletion of the homologous yeast gene SNA1. Plant Mol. Biol. 2001, 45, 341-352. [CrossRef] [PubMed]

68. Sivankalyani, V.; Geetha, M.; Subramanyam, K.; Girija, S. Ectopic expression of arabidopsis RCI2A gene contributes to cold tolerance in tomato. Transgenic Res. 2014, 24, 237-251. [CrossRef] [PubMed]

69. Anjum, S.A.; Farooq, M.; Xie, X.-Y.; Liu, X.-J.; Ijaz, M.F. Antioxidant defense system and proline accumulation enables hot pepper to perform better under drought. Sci. Hortic. 2012, 140, 66-73. [CrossRef]

70. Tabot, P.T.; Adams, J.B. Salt secretion, proline accumulation and increased branching confer tolerance to drought and salinity in the endemic halophyte Limoniumlinifolium. S. Afr. J. Bot. 2014, 94, 64-73. [CrossRef]

71. Zhu, H.S.; Yu, X.J.; Zhao, X.; Dong, K.H.; Yang, W.D. The activity and gene expression levels of p5cs and delta-oat in Medicago sativa cvpianguan under drought stress. Pak. J. Bot. 2016, 48, 137-142.

72. Szabados, L.; Savouré, A. Proline: A multifunctional amino acid. Trends Plant Sci. 2010, 15, 89-97. [CrossRef]

73. Krannich, C.T.; Maletzki, L.; Kurowsky, C.; Horn, R. Network candidate genes in breeding for drought tolerant crops. Int. J. Mol. Sci. 2015, 16, 16378-16400. [CrossRef]

74. Liang, C.e.a. GhABF2, a bzip transcription factor, confers drought and salinity tolerance in cotton (Gossypiumhirsutum L.). Sci. Rep. 2016, 6, 35040. [CrossRef] [PubMed]

75. Liu, C.; Mao, B.; Ou, S.; Wang, W.; Liu, L.; Wu, Y.; Chu, C.; Wang, X. OsbZIP71, a bZIP transcription factor, confers salinity and drought tolerance in rice. Plant Mol. Biol. 2014, 84, 19-36. [CrossRef] [PubMed]

76. Abogadallah, G.M.; Nada, R.M.; Malinowski, R.; Quick, P. Overexpression of HARDY, an AP2/ERF gene from arabidopsis, improves drought and salt tolerance by reducing transpiration and sodium uptake in transgenic Trifoliumalexandrinum L. Planta 2011, 233, 1265-1276. [CrossRef] [PubMed]

77. Marcolino-Gomes, J.; Rodrigues, F.A.; Oliveira, M.C.N.; Farias, J.R.B.; Neumaier, N.; Abdelnoor, R.V.; Marcelino-Guimarães, F.C.; Nepomuceno, A.L. Expression patterns of GMAP2/EREB-like transcription factors involved in soybean responses to water deficit. PLoS ONE 2013, 8, e62294. [CrossRef] [PubMed]

78. Mun, B.-G.; Lee, S.-U.; Park, E.-J.; Kim, H.-H.; Hussain, A.; Imran, Q.M.; Lee, I.-J.; Yun, B.-W. Analysis of transcription factors among differentially expressed genes induced by drought stress in Populusdavidiana. 3 Biotech 2017, 7, 209. [CrossRef] [PubMed]

79. Huang, X.-Y.; Chao, D.-Y.; Gao, J.-P.; Zhu, M.-Z.; Shi, M.; Lin, H.-X. A previously unknown zinc finger protein, DST, regulates drought and salt tolerance in rice via stomatal aperture control. Genes Dev. 2009, 23, 1805-1817. [CrossRef] [PubMed] 
80. Kiegerl, S.; Cardinale, F.; Siligan, C.; Gross, A.; Baudouin, E.; Liwosz, A.; Eklöf, S.; Till, S.; Bögre, L.; Hirt, H.; et al. SIMKK, a mitogen-activated protein kinase (MAPK) kinase, is a specific activator of the salt stress-induced MAPK, SIMK. Plant Cell 2000, 12, 2247-2258. [CrossRef]

81. Ning, J.; Li, X.; Hicks, L.M.; Xiong, L. A Raf-like MAPKKK gene DSM1 mediates drought resistance through reactive oxygen species scavenging in rice. Plant Physiol. 2010, 152, 876-890. [CrossRef]

82. Golldack, D.; Li, C.; Mohan, H.; Probst, N. Tolerance to drought and salt stress in plants: Unraveling the signaling networks. Front. Plant Sci. 2014, 5, 151. [CrossRef]

83. Sinha, A.K.; Jaggi, M.; Raghuram, B.; Tuteja, N. Mitogen-activated protein kinase signaling in plants under abiotic stress. Plant Signal. Behav. 2011, 6, 196-203. [CrossRef]

84. Shivakumara, T.N.; Sreevathsa, R.; Dash, P.K.; Sheshshayee, M.S.; Papolu, P.K.; Rao, U.; Tuteja, N.; UdayaKumar, M. Overexpression of pea DNA helicase 45 (PDH45) imparts tolerance to multiple abiotic stresses in chili (Capsicum annuum L.). Sci. Rep. 2017, 7, 2760. [CrossRef] [PubMed]

85. Blum, A. Heterosis, stress, and the environment: A possible road map towards the general improvement of crop yield. J. Exp. Bot. 2013, 64, 4829-4837. [CrossRef] [PubMed]

86. Baranwal, V.K.; Mikkilineni, V.; Zehr, U.B.; Tyagi, A.K.; Kapoor, S. Heterosis: Emerging ideas about hybrid vigour. J. Exp. Bot. 2012, 63, 6309-6314. [CrossRef] [PubMed]

87. Fu, D.; Xiao, M.; Hayward, A.; Jiang, G.; Zhu, L.; Zhou, Q.; Li, J.; Zhang, M. What is crop heterosis: New insights into an old topic. J. Appl. Genet. 2015, 56, 1-13. [CrossRef] [PubMed]

88. Barnaby, J.Y.; Kim, M.; Bauchan, G.; Bunce, J.; Reddy, V.; Sicher, R.C. Drought responses of foliar metabolites in three maize hybrids differing in water stress tolerance. PLoS ONE 2013, 8, e77145. [CrossRef] [PubMed]

(C) 2019 by the authors. Licensee MDPI, Basel, Switzerland. This article is an open access article distributed under the terms and conditions of the Creative Commons Attribution (CC BY) license (http:// creativecommons.org/licenses/by/4.0/). 